\title{
AMERICAN TEGUMENTARY LEISHMANIASIS: LANGERHANS CELLS IN MONTENEGRO SKIN TEST
}

\author{
Marcia Ferraz NOGUEIRA(1), Mírian N. SOTTO(2) \& Luiz Carlos CUCÉ(3)
}

\begin{abstract}
SUMMARY
This work analyzed the histopathology and epidermal Langerhans cells (LC) of Montenegro skin test (MST) in patients with American tegumentary leishmaniasis (ATL) in order to in situ characterize and compare the immunological reaction of the two major clinical forms of ATL, localized cutaneous leishmaniasis (LCL) and mucocutaneous leishmaniasis (MCL). MST histopathology of both LCL and MCL showed superficial and deep perivascular inflammatory infiltrate composed mainly of lymphocytes and histiocytes. Epidermal LC population was higher in MST biopsies taken from LCL patients when compared to MCL group, at 48 and 72 hours after antigen inoculation. Increased number of epidermal LC displayed in MST biopsies of LCL patients represents specific cellular immunity against parasites. The decrease of LC in MST biopsies of MCL patients does not necessarily indicate a worse specific cellular immunity in this clinical form of leishmaniasis.
\end{abstract}

KEYWORDS: Cutaneous leishmaniasis; Delayed type hypersensitivity; Immunopathology; Skin; Langerhans cells.

\section{INTRODUCTION}

Leishmaniasis is an infectious disease caused by the protozoan genus Leishmania. It is a zoonosis in which man act as incidental host. Leishmania is an obligate intracellular parasite of vertebrate hosts, and requiring an invertebrate vector, from Class Insecta- phlebotomine sand fly species to complete its vital cycle ${ }^{12}$.

American tegumentary leishmaniasis (ATL) affects the skin and mucosa. The most frequent forms in the state of São Paulo are localized cutaneous leishmaniasis (LCL) and mucocutaneous leishmaniasis (MCL). LCL is characterized by skin ulcers with infiltrated erythematous borders, with coarse and secreting granulose base, specially located in exposed areas of the body. MCL is characterized by ulcerated and infiltrated lesions in oral, nasal, pharyngeal and laryngeal mucous membranes, with compromise of the skin surrounding the nasal mucosa. Mucosal lesions appear two or more years after the healing of skin ulcer. The development of these forms of the disease depends on the host's immune system and the species of Leishmania ${ }^{12}$.

The diagnosis of ATL is confirmed by the demonstration of the parasite in the lesions. The parasites are frequently scarce, and difficult to find in the lesions. In these cases the Montenegro skin test (MST) is useful to confirm the diagnosis of the disease ${ }^{14}$.

MST consists of intradermal injection of $0.1 \mathrm{~mL}$ of a suspension with $3-4.5 \times 10^{6}$ dead promastigotes. The positive result to this test is considered the expression of cellular immunity of the host to the parasite $^{14}$.
Immunity depends on both the host immune system and Leishmania species. The immune response against Leishmania may be effective enough to protect host from the development of disease. Otherwise, effective immunity is present in LCL. Exacerbated immunity is the cause of destructive and recurrent mucosal lesions. Non effective immunity leads to anergy with disseminated skin lesions $\mathbf{s}^{3,4,10,12}$.

MST is a delayed hypersensitivity reaction, characterized by type IV immune response, mimicking the granulomatous inflammatory reaction that occurs in leishmaniotic lesions ${ }^{3-5,9-12,14,15}$. All patients with LCL and MCL exhibit positive MST. The sensitivity and specificity of MST range from 83.7 to $100 \%$. MST remains indefinitely positive, even after the cure of the disease. However, this concept was questioned by other authors. MST intensity is greater in patients that present long lasting disease and MCL form of the disease. The aggressiveness of MCL is related to the intensity of MST. However, exacerbated responses (with papule greater than $10 \mathrm{~mm}$ in diameter) are not exclusive of $\mathrm{MCL}^{3,5,9,10,12,14}$.

The purpose of this study was to analyze MST in LCL and MCL, by assessing and comparing the intensity of reaction, histological features and quantification of Langerhans cells, in an attempt to identify immunological differences between these two clinical forms of the disease.

\section{MATERIAL AND METHODS}

The casuistic comprehends four LCL and six MCL patients followed up at the University of S. Paulo Medical School - Division of Dermatology. The study was approved by the research ethics board of 
the Institution. Informed consent was obtained from all patients. The patients were male, with age ranging from 19 to 82 years (mean 49.9 years). Nine patients were from different regions of Brazil and one from Bolivia (patient 3).

The diagnosis of leishmaniasis was confirmed by positive MST, anti-Leishmania antibody demonstrated by indirect immune fluorescence and/or ELISA assay, and demonstration of parasites in lesions smears or biopsy exam with Leishmania antigen demonstration by immunoperoxidase technique ${ }^{16}$.

Montenegro skin test: All patients were subjected to an intradermal injection of $100 \mu \mathrm{L}$ of dead Leishmania promastigotes suspension (2 to $3 \times 10^{6}$ parasites, called Montenegro antigen, produced at Adolfo Lutz Institute, in São Paulo, Brazil) for three times (at the same day) in three randomly selected points located on the right and left arms.

The clinical evaluation of MST was made 72 hours after inoculation. The results were expressed by the two diameters of the papules or nodules. The mean of the two diameters were calculated for statistical analysis. MST was considered positive when the diameter of the resulting erythematous papule/nodule was $\geq 5 \mathrm{~mm}$.

Histopathology: Skin biopsies were obtained in the centre of the erythematous papule, using $4 \mathrm{~mm}$ punch, under local anesthesia with $2 \%$, xylocaine, after the clinical evaluation of MST. Four samples were taken from each patient. The first biopsy was taken 24 hours after antigen inoculation; the second one, after 48 hours and the third one, after 72 hours. The fourth biopsy was taken from normal skin for control purposes. Each skin fragment was cut in two. One was fixed in $10 \%$ formalin and processed to histopathological exam. The other fragment was snap frozen and preserved in liquid Nitrogen until processed to immunohistochemistry.

Demonstration of Langerhans Cells by immunohistochemical technique: Five $\mu \mathrm{m}$ fragments of each biopsy were cut in cryostat and fixed in acetone, incubated with mouse monoclonal anti-CD1a antibody (Dako, NA 1/34 code M721, Carpinteria, CA, USA) and treated by avidin-biotin method modified as previously described. The reaction was developed using $0.06 \%$ hydrogen peroxide and $0.3 \mathrm{mg} / \mathrm{mL}$ 3,3'-diaminobenzidine (Sigma Chemical, USA) in phosphate buffered saline and nickel chloride. Counterstaining was performed with methyl green. The Langerhans cells were immunolabeled in black color.

Quantification of Langerhans cells: Epidermal CD1a immunolabeling area (Langerhans cells) were measured with image analysis system (Quantimet 500 Color System Qein V02.00A, Leica Cambridge Ltd.) using a microcomputer 486DX 33 equipped with multimedia video interface with a microscope (Leica Diastar) and video camera (JVC TK-1280V-color). Five random epidermal fields $(\times 200$ magnification), excluding stratum corneum and basal layer, were evaluated for each biopsy. The results were expressed in $\mu \mathrm{m}^{2}$.

Statistical analyses: The MST evaluation results at 24, 48 and 72 hours post antigen inoculation were compared by chi square test.

The results of Langerhans cells evaluation of normal skin and MST biopsies of LCL and MCL patients, as well as MST biopsies of both group of patients were compared by Mann-Whitney test.
The level of significance was set at $p \leq 0.05$.

\section{RESULTS}

Intensity of Montenegro Skin Test: MST in LCL patients, at 24, 48 and 72 hours, exhibited papule or nodule with mean area of 100, 25, 49 and $100 \mathrm{~mm}^{2}$ respectively. In MCL group MST mean area of the three antigen inoculation sites were $225,100,196$ and $100 \mathrm{~mm}^{2}$, respectively. The intensity of MST in LCL was lower than in MCL $(p<0.05)$ (see Table 1$)$.

Table 1

Intensity of Montenegro skin test in localized cutaneous leishmaniasis (LCL) and mucocutaneous leishmaniasis (MCL) $\left(\mathrm{mm}^{2}\right)$

\begin{tabular}{cccc}
\hline $\begin{array}{c}\text { Groups } \\
\mathrm{n}=\text { number of cases }\end{array}$ & $\begin{array}{c}\text { LCL } \\
\mathrm{n}=4\end{array}$ & $\begin{array}{c}\text { MCL } \\
\mathrm{n}=6\end{array}$ & \\
\hline $\begin{array}{c}\text { Mean } \pm \text { Standard } \\
\text { deviation }\end{array}$ & $68.5 \pm 37.7$ & $157.7 \pm 64.0$ & \\
Range & $25-100$ & $100-225$ & $p<0.05^{*}$ \\
Median & 74.5 & 148 & \\
\hline
\end{tabular}

$* \chi^{2}$ test.

Histopathology of MST: Twenty nine MST skin biopsies were analyzed: 12 of LCL and 17 of MCL patients. The biopsy taken at 48 hour after antigen inoculation of case 6 was excluded because the specimen was insufficient for the analysis.

The skin biopsies of MST revealed microscopic alterations in all assessed times (24, 48 and 72 hours) in both LCL and MCL groups. The epidermis showed acanthosis, spongiosis, basal cells vacuolar alteration and lymphocytic exocytosis. Less frequently, apoptosis, epidermal vesiculation, exulceration and necrosis were also seen.

Superficial and superficial and deep perivascular inflammatory infiltrate, composed lymphocytes and histiocytes, and a few of neutrophils and eosinophils, were the main dermal alteration. The 72 hours post antigen inoculation samples presented the most severe alterations. Necrosis was observed in $75 \%$ of LCL patients and in $50 \%$ of MCL specimens. Granulomatous reaction, with mild clusters of epithelioid cells, was observed in $83 \%$ of the samples of MCL and in only one specimen of LCL group. Interstitial edema, leukocytoclasia and vasculitis were observed in few specimens.

Demonstration, quantification and comparison of Langerhans cells in MST: The control skin of both groups displayed immunostained LC with anastomosing dendrites in epidermal spinous layer, intermingled between keratinocytes. MST biopsies at 24 hours after antigen inoculation, of LCL and MCL patients did not differ from control skin. At 72 hours post antigen inoculation, MST of LCL patients exhibited numerous LC, distributed among spinous layer keratinocytes. MCL specimens, taken at 48 and 72 hours after antigen inoculation, displayed few LC in comparison to normal skin. These cells exhibited short and irregular dendrites.

Results of the quantification of Langerhans cells in MST biopsies of LCL and MCL groups, expressed by CD1a immunolabeled epidermal area, are demonstrated in Table 2. 
Table 2

Langerhans cells disclosed by CD1a epidermal expression $\left(\mu \mathrm{m}^{2}\right)$ in localized cutaneous leishmaniasis (LCL) and mucocutaneous leishmaniasis (MCL)

\begin{tabular}{llcccc}
\hline Groups & & Normal skin & $\begin{array}{c}24 \text { hours after antigen } \\
\text { inoculation }\end{array}$ & $\begin{array}{c}\text { 48 hours after antigen } \\
\text { inoculation }\end{array}$ & $\begin{array}{c}72 \text { hours after antigen } \\
\text { inoculation }\end{array}$ \\
\hline LCL & Mean \pm SD & $370.2 \pm 237.5$ & $341.9 \pm 136.6$ & $399.0 \pm 131.4$ & $606.8 \pm 299.1$ \\
& Range & $73.3-1191.9$ & $162.8-708.1$ & $181.4-667.1$ & $134.1-1316.8$ \\
& Median & $297.7^{\mathrm{a}}$ & 320.6 & $398.6^{\mathrm{b}}$ & $630.4^{\mathrm{c}}$ \\
\multirow{3}{*}{ MCL } & Mean \pm SD & $360.5 \pm 146.1$ & $294.4 \pm 131.5$ & $161.5 \pm 91.4$ & $125.1 \pm 97.1$ \\
& Range & $127.7-636.7$ & $63.6-585.8$ & $40.8-359.8$ & $0-358.4$ \\
& Median & $335.8^{\mathrm{d}}$ & 296.8 & $146.8^{\mathrm{e}}$ & $93.7^{\mathrm{f}}$ \\
\hline
\end{tabular}

SD: standard deviation; a $<\mathrm{c}(p<0.05) ; \mathrm{d}>\mathrm{e}(p<0.001)$; $>\mathrm{f}(p<0.001)$; b $>\mathrm{e}(p<0.001) ; \mathrm{c}>\mathrm{f}(p<0.001)$ - Mann-Whitney test.

Epidermal Langerhans cells population in MST biopsies of LCL group, taken at 72 hours after antigen inoculation, differed from normal skin $(p \leq 0.05)$. In the MCL group, there were statistically significant differences between normal skin LC population at 48 hours $(p \leq 0.001)$ and 72 hours $(p \leq 0.001)$ post antigen inoculation biopsies.

Langerhans cells population was higher in MST biopsies of LCL patients (at 48 and 72 hours after inoculation) when compared to MST specimens of MCL patients $(p \leq 0.001)$.

\section{DISCUSSION}

MST is a cellular immune reaction of delayed hypersensitivity ${ }^{9,10}$. This reaction presents high sensitivity in patients with ATL, with current or past infection. Its positive score ranges from $82.4 \%$ to $100 \%$. MST is considered a generic group-specific reaction, since patients with ATL develop positive response to antigens of different species of Leishmania and to antigens of protozoan genus Trypanosoma. The positive result of the reaction express the effectiveness of cellular immunity in LCL and MCL forms of the disease. Whereas MST is negative in diffuse (anergic) form of $\mathrm{ATL}^{3,5,9,10,12,14}$.

Positive MST in subjects of endemic areas that do not present history or signs of past disease indicates subclinical infection. Positive reactions in patients with leishmaniasis may reflect the development of host cellular immunity, which indicates protection to potential recurrence of the disease or new infections ${ }^{4,10,12}$.

In the present study, we observed a significant difference $(p \leq 0.05)$ between MST intensity in LCL and in MCL patients. In MLC patients MST exhibited higher intensity. Otherwise two (50\%) LCL patients presented MST with $10 \mathrm{~mm}$ papule, which is considered strongly positive result ${ }^{9,10}$.

Intensity of MST is determined by host characteristics that comprehend the type and number of lesions, duration of active disease and time up to cure. It is considered also a reflection of the patient's degree of cellular immunity. The most intense reactions are expression of an exacerbated cellular immunity. This event is observed in patients with MCL who developed more aggressive lesions. This feature could be explained by the hyper reactive response. Patients with LCL present immunity against Leishmania, developing skin lesion, which may progress to spontaneous healing. MCL patients acquire protective immunity against Leishmania, but it is not enough to protect them from severe mucocutaneous lesions ${ }^{9,10}$.

There is disagreement in the literature concerning the intensity of MST. This is due to the fact that there is no standardized and reliable methodology to measure the intensity of the reaction.

Histopathology of Montenegro Skin Test: The histopathological alterations observed in skin biopsies of MST taken 24, 48 and 72 hours after the antigen inoculation exhibited similar features in both LCL and MCL patients. These histopathological features were similar to those described by other authors ${ }^{10,15}$.

Langerhans cells in Montenegro Skin Test: As Langerhans cells quantification in normal epidermis varies according to anatomical location ${ }^{11}$, the normal skin control group was taken from the same body area as the MST specimens.

We observed a higher LC population in MST epidermis of LCL patients within 72 hours after antigen inoculation when in comparison to normal skin $(p=0.05)$. In MCL group the LC population at MST taken 48 and 72 hours post antigen inoculation, was lower than in normal skin group $(p=0.001)$.

LCL presents increased LC in the cutaneous lesions. In DCL lesions there is a reduction of those cells in comparison to LCL. Otherwise the number of LC in DCL is higher than in normal skin. MCL presents absence of epidermal LC in its lesions s,8,17,18. $^{7}$.

The role of LC in experimental and human tegumentary leishmaniasis has been widely studied ${ }^{13,20}$. LC plays a key role in antigen presentation and is capable of phagocytize the parasite ${ }^{1,2}$.

The obtained data on MST of LCL patients, in which we detected an increase of epidermal LC, were in agreement to previously description on tuberculin reaction ${ }^{11}$. In MST of MCL patients LC were reduced in the epidermis. Their migration to dermis may be due to an attempt to start the cellular immune response of MCL, as demonstrated to tuberculin reaction of lepromatous patients previously sensitized to M. tuberculosis ${ }^{11}$.

LC is essential to trigger and maintaining cellular immune response ${ }^{13}$. It may explain why LC are absent in MCL lesions. The absence of these cells results in development of chronic and destructive lesions observed in this form of leishmaniasis ${ }^{3,17}$. 
Our study demonstrated and quantified LC in MST biopsies in an attempt to better analyze the reaction. It is important to keep in mind that MST and the granulomatous reaction of leishmaniasis are examples of delayed hypersensitivity reaction. Thus, it is possible to make an analogy of LC behavior in MST and in leishmaniotic lesions.

Even though some authors have stated that both LCL and MCL present cellular immunity, our study adds that the in situ cellular immune response expressed by MST is different in LCL and MCL.

MCL patients displayed reduction of Langerhans cells in MST biopsies. This result is similar to what is observed in the lesions of this form of disease. These data suggest that MCL cellular immune response is different from LCL, especially at the beginning of the defense process. At 48 hours after antigen inoculation MCL patients presented decrease of LC in comparison to normal skin. This event was not observed in LCL group. This observation may represent an early immunological process in MLC. However, it is still to be defined if this early immune response is effective against the parasite.

The obtained data suggest that the quantification of Langerhans cells in MST is a tool to characterize differences in specific cellular immunity of LCL and MCL. It is better to display these differences than only evaluating the intensity and/or the histopathology of MST.

\section{RESUMO}

\section{Leishmaniose tegumentar americana: células de Langerhans na reação intradérmica de Montenegro}

Este trabalho analisou e quantificou as células de Langerhans e as características histopatológicas da reação de Montenegro nos pacientes com leishmaniose tegumentar americana (LTA) para caracterizar seu comportamento imunológico nas duas formas clínicas mais comuns da LTA, a leishmaniose cutânea localizada (LCL) e a leishmaniose cutâneomucosa (LCM). O exame histopatológico apresentou infiltrado inflamatório perivascular superficial e profundo, com predomínio de histiócitos e linfócitos, sem diferença significante entre as duas formas da doença. $\mathrm{O}$ resultado da quantificação das CL apresentou aumento das CL na LCL e diminuição na LCM em 48 e 72 horas após a inoculação do antígeno ( $p$ $<0,001)$. O aumento das células de Langerhans epidérmicas na reação de Montenegro da LCL demonstra a presença de imunidade celular específica, enquanto a diminuição das mesmas células na LCM não necessariamente demonstra uma diminuição da imunidade celular específica.

\section{ACKNOWLEDGMENTS}

We thank Mr. Cleiton Alves for technical assistance in immunohistochemistry.

\section{REFERENCES}

1. BLANK, C.; FUCHS, H.; RAPPERSBERGER, K.; RÖLLINGHOFF, M. \& MOLL, H. - Parasitism of epidermal Langerhans cells in experimental cutaneous leishmaniasis with Leishmania major. J. infect. Dis., 167: 418-425, 1993.

2. CÁCERES-DITTMAR, G.; SANCHEZ, M.A.; ORIOL, O.; KRAAL, G. \& TAPIA, F.J. - Epidermal compromise in American cutaneous leishmaniasis. J. invest. Derm., 99(suppl. 5): 95s-98s, 1992.
3. CASTES, M. \& TAPIA, F.J. - Imunopatologia de la leishmaniasis tegumentaria americana. Acta cient. venez., 49: 42-56, 1998.

4. COUTINHO, S.G.; PIRMEZ, C.; MENDONÇA, S.C.F.; CONCEIÇÃO-SILVA, F. \& DOREA, R.C.C. - Pathogenesis and immunopathology of leishmaniasis. Mem. Inst. Oswaldo Cruz, 82(suppl.): 214-228, 1987.

5. CUCÉ, L.C.; OLIVEIRA FILHO, J. \& FESTA NETO, C. - Intradermorreação de Montenegro e imunofluorescência indireta em familiares de doentes com leishmaniose tegumentar americana. An. bras. Derm., 54: 245-250, 1979.

6. DOMPMARTIN, A.; HEALY, A.T.; NACY, C.A.; HAUSER, C. \& MELTZER, M.S. Leishmania major infects and replicates within murine epidermal Langerhans cells. [Abstract]. J. invest. Derm., 91: 404, 1988.

7. EL HASSAN, A.M.; GAAFAR, A. \& THEANDER, T.G. - Antigen-presentig cells in human cutaneous leishmaniasis due to Leishmania major. Clin. exp. Immunol., 99: 445-453, 1995.

8. ESTERRE, P.; DEDET, J.P.; FRENAY, C.; CHEVALLIER, M. \& GRIMAUD, J.A. - Cell populations in the lesion of human cutaneous leishmaniasis: a light microscopical, immunohistochemical and ultrastructural study. Virchows Arch. A Path. Anat. Histopath., 421: 239-247, 1992.

9. FESTA NETO, C.; SOTTO, M.N. \& CUCÉ, L.C. - Intradermorreação de Montenegro: aspectos histopatológicos e imunológicos. Med. cut. ibero lat.-amer., XIX: 293-301, 1991.

10. GUEDES, A.C.M. - Contribuição ao estudo da reação de Montenegro. Belo Horizonte, 1980. (Dissertação de Mestrado - Faculdade de Medicina da Universidade Federal de Minas Gerais).

11. KAPLAN, G.; NUSRAT, A.; WITMER, M.D.; NATH, I. \& COHN, Z.A. - Distribution and turnover of Langerhans cells during delayed immune responses in human skin. J. exp. Med., 165: 763-776, 1987.

12. MAGILL, A.J. - Epidemiology of the leishmaniasis. Derm. clin., 13: 505-523, 1995.

13. MOLL, H.; FUCHS, H.; BLANK, C. \& ROLLINGHOFF, M. - Langerhans cells transport Leishmania major from the infected skin to the draining lymph node for presentation to antigen-specific T cells. Europ. J. Immunol., 23: 1595-1601, 1993.

14. MONTEnEGro, J. - A cutis-reação na leishmaniose. An. Fac. Med. S. Paulo, 1: 323 330,1926

15. MONTENEGRO, J. - Anátomo-pathologia da leishmaniose cutânea (úlcera de Bauru). An. paul. Med. Cirurg., 15: 5-11, 1924.

16. SOTTO, M.N.; YAMASHIRO-KANASHIRO, E.H.; MATTA, V.L.R. \& BRITO, T. Cutaneous leishmaniasis of the New World: diagnostic immunopathology and antigen pathways in skin and mucosa. Acta trop., 46: 121-130, 1989.

17. TAPIA, F.J.; CÁCERES-DITTMAR, G.; ACUÑA, L. \& MOSCA, W. - Epidermal Langerhans cells in infectious diseases. Histol. Histopath., 4: 499-508, 1989.

18. TAPIA, F.J.; CÁCERES-DITTMAR, G.; SANCHEZ, M.A. et al. - Adhesion molecule in lesions of American cutaneous leishmaniasis. Exp. Derm., 3: 17-22, 1994.

19. XAVIER, M.B.; SILVEIRA, F.T.; DEMACHKI, S.; FERREIRA, M.M. \& DO NASCIMENTO, J.L. - American tegumentary leishmaniasis: a quantitative analysis of Langerhans cells presents important differences between $L$. (L.) amazonensis and Viannia subgenus. Acta trop., 95: 67-73, 2005.

20. ZULUAGA, M. \& ROBLEDO, S.M. - Las células de Langerhans en la immunidad a leishmaniasis. Biomedica, 24: 302-317, 2004.

Received: 4 March 2008

Accepted: 11 September 2008 